\title{
PENGEMBANGAN MODUL ELEKTRONIK MATA KULIAH SISTEM DIGITAL UNTUK PROGRAM STUDI PENDIDIKAN TIK
}

\author{
N Nurbani*, Sri Koriaty ${ }^{2}$ Henny Puspitasari ${ }^{3}$ \\ ${ }^{1,2,3}$ Pendidikan Teknologi Informasi dan Komputer, IKIP PGRI Pontianak, Jalan Ampera Nomor 88 \\ Pontianak Kalimantan Barat Indonesia \\ *email: nurbani05@gmail.com
}

\section{Received: 19 Maret 2019 Accepted: 1 Juni 2019 Published: 30 Juni 2019}

\begin{abstract}
Abstrak
Penelitian ini bertujuan untuk mengembangkan modul elektronik pada matakuliah Sistem Digital. Penelitian ini adalah penelitian pengembangan (Research and Development). Model Pengembangan yang digunakan adalah model Borg and Gall. Objek penelitian ini adalah mahasiswa semester III Prodi Pendidikan TIK Pontianak tahun 2018/2019 Hasil penelitian menunjukkan bahwa modul elektroni aplikasi Sistem Digital yang dikembangkan layak dan baik digunakan dalam proses pembelajaran TIK. Hal ini didukung oleh penilaian modul elektronik oleh dosen ahli materi diperoleh skor 102,5, dengan kriteria layak dan hasil penilaian modul elektronik oleh dosen ahli media diperoleh skor 94,5 dengan kriteria layak. Sedangkan respon mahasiswa terhadap modul elektronik dalam ujicoba sampel 92 mahasiswa diperoleh rata-rata skor angket 3,9 dengan kriteria baik.
\end{abstract}

Kata kunci: pengembangan, modul, sistem digital

\section{Abstract}

This study aims to develop electronic modules in the Digital Systems course. This research is research and development. The Development Model used is the Borg and Gall model. The object of this study was the third-semester students of Pontianak ICT Education Study Program in 2018/2019. The results of the study showed that the electronic module application of the Digital System developed was feasible and well used in the ICT learning process. This is supported by the assessment of electronic modules by material expert lecturers obtained a score of 102.5, with eligible criteria and the results of the electronic module assessment by media expert lecturers, obtained a score of 94.5 with eligible criteria. While the response of students to electronic modules in the trial sample of 92 students was obtained an average score of 3.9 questionnaires with good criteria.

Keywords: development, electronic modules, digital systems

(C) 2019 LPPM IKIP PGRI Pontianak, Indonesia

\section{PENDAHULUAN}

Teknologi pendidikan adalah suatu proses yang kompleks dan terpadu yang meliputi manusia, prosedur, ide, alat, dan organisasi untuk menganalisis masalah serta merancang, melaksanakan, menilai, dan mengelolah usaha pemecahan masalah yang berhubungan dengan segala aspek belajar (Mudhofir, 1990). Perkembangan teknologi yang begitu pesat menawarkan 
kebutuhan dalam pembelajaran. Hal ini memungkinkan terjadinya perubahan cara belajar, dari belajar dengan guru di sekolah menjadi belajar mandiri. Belajar mandiri adalah cara efektif mengembangkan diri yang tidak terikat dengan kehadiran guru, pertemuan tatap muka, dan kehadiran di sekolah. Belajar mandiri membutuhkan motivasi, keuletan, keseriusan, tanggungjawab, dan keingintahuan untuk berkembang dan maju. Untuk memudahkan belajar mandiri perlu adanya media yang menunjang tugas-tugas dosen memotivasi dan meningkatkan pemahaman mahasiswa. Alat bantu secara nyata sangat membantu aktifitas pembelajaran dikelas untuk meningkatkan minat serta hasil belajar.

Mata kuliah Sistem Digital merupakan salah satu mata kuliah yang dipelajari oleh mahasiswa semester III Program Studi P.TIK IKIP-PGRI Pontianak. Berdasarkan hasil observasi bulan Maret 2018 dan wawancara dengan dosen pengampu matakuliah Sistem Digital, peneliti mendapati bahwa motivasi berfikir kritis dan keterampilan mahasiswa masih kurang. Bahan ajar juga masih terbatas buku teks yang tersedia di perpustakaan, mahasiswa masih perlu menggunakan bahan ajar lain untuk melatih kemampuan dan keterampilan dalam berfikir kritis.

Berdasarkan hasil analisis kebutuhan awal dosen dan mahasiswa yang masih membutuhkan bahan ajar yang bersifat terpadu dan mampu melatih kemampuan mahasiswa dalam keterampilan. Salah satu bentuk bahan ajar adalah modul. Modul adalah satuan program pembelajaran terkecil yang dapat dipelajari mahasiswa secara perorangan karena dapat membantu mahamahasiswa dalam mempelajari dan memahami serta menyelesaikan tugas secara mandiri.

Telah banyak penelitian yang dilakukan untuk mengembangkan modul. Salah satunya dilakukan oleh Ningsih, Hasyim \& Fitriawan (2013) yaitu dengan judul pengembangan Bahan Ajar Multimedia Interaktif Srandar Kompetensi Menggambar Dengan Perangkat Lunak Autocad Bagi Siswa SMK Di Lampung. Najikhah, Budiyono \& Wardi (2015) mengembangkan MPI game edukasi dengan adobe flash dengan baik, mulai dari tampilan, interaktifitas dan fasilitasfasilitas yang tersedia sudah memenuhi kriteria sebuah pembelajaran yang baik. Selanjutnya pelaksanaan pembelajaran IPA mengenal berbagai benda langin dengan memanfaatkan MPI game edukasi ini menunjukkan hasil yang baik, dimana terdapat peningkatan hasil belajar sebelum dan sesudai menggunakan media. Modul yang dikembangkan dalam penelitian ini lebih komplek dibandingkan dengan modul-modul sebelumnya karena dilengkapi dengan menu evaluasi. Dengan adanya menu evaluasi ini diharapkan. Pengembangan modul ini diharapkan 
dapat mengembangkan keterampilan mahasiswa sehingga berdampak pada hasil belajar yang lebih baik. Selain itu pengembangan bahan ajar dengan multimedia diharapkan dapat memberikan sumbangan pemikiran kepada guru atau dosen untuk diterapkan pada proses pembelajaran.

\section{METODE}

Metode penelitian yang digunakan dalam penelitian ini adalah penelitian dan pengembangan (Research and Development). Menurut Sugiyono (2014) metode penelitian dan pengembangan atau Research and Development adalah metode penelitian yang digunakan untuk menghasilkan produk tertentu, dan menguji keefektifan produk tersebut. Penelitian ini difokuskan pada pengembangan modul elektronik. Metode penelitian Research and Development mempunyai langkah-langkah sebagai yang di tunjukkan pada Gambar 1.

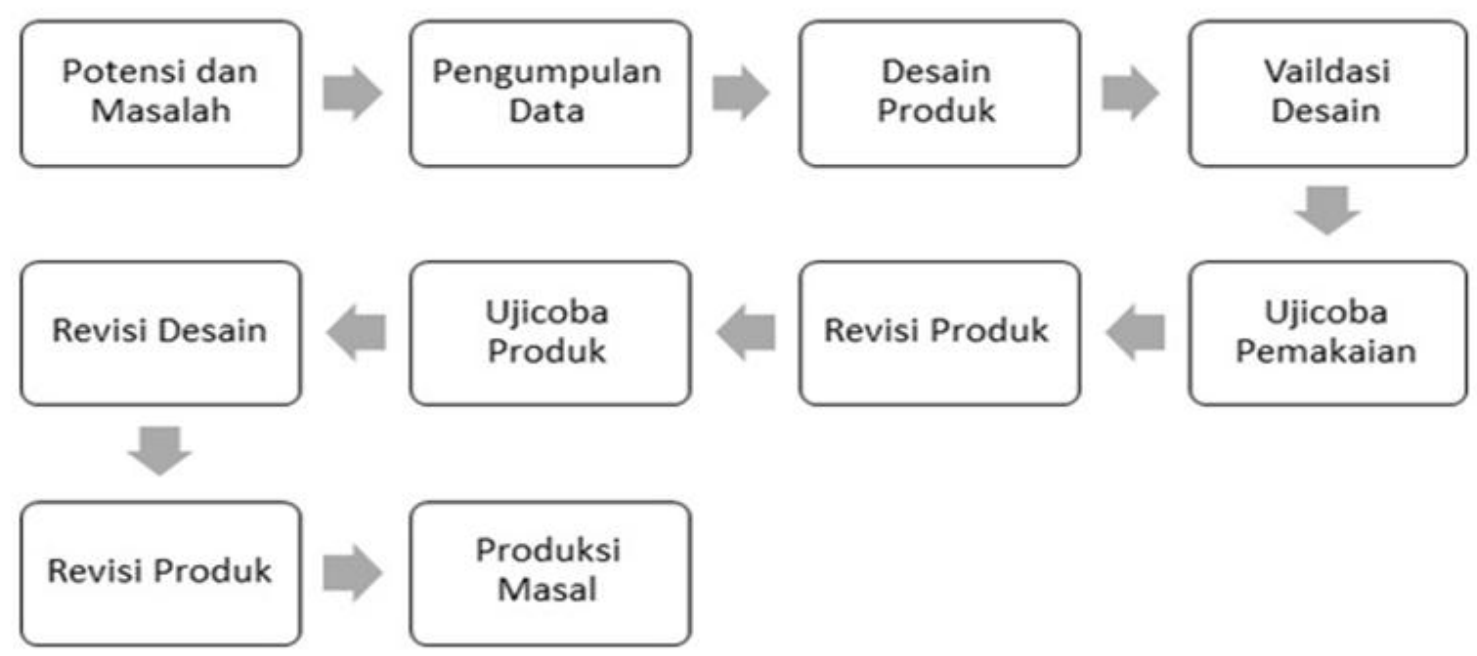

Gambar 1. Langkah-langkah Research and Development

Potensi dan masalah yaitu mencari informasi atau data terkait hal apa yang dibutuhkan guna menyelesaikan masalah di lokasi tersebut. Tahap selanjutnya yaitu pengumpulan data yaitu peneliti mengumpulkan data apa saja yang diperlukan sesuai dengan yang dibutuhkan. Kemudian desain produk yaitu perancangan draf awal produk pembelajaran yang siap di uji cobakan beserta instrument validasi. Validasi desain merupakan tahap memvalidasi produk yang sudah di desain oleh orang yang ahli dalam bidangnya. Revisi desain merupakan tahap memperbaiki hasil revisi dari ahli mengenai produk yang telah dibuat untuk mengetahui kelayakannya. Ujicoba produk merupakan uji coba utama dengan skop yang lebih luas, bisa 30 sampai 100 subjek uji coba. 
Revisi produk ini merupakan tahapan perbaikan kedua setelah dilakukan uji lapangan yang lebih luas. Uji coba pemakaian melibatkan 40 sampai dengan 200 subjek. Tujuan dari tahap ini adalah untuk menentukan apakah suatu produk yang dikembangkan itu benar-benar siap dipakai

Subjek penelitian ini adalah mahasiswa semester III Prodi TIK IKIP-PGRI Pontianak. Instrumen penelitian yang digunakan yaitu wawancara. Dalam penelitian ini wawancara dilakukan kepada dosen pengampu matakuliah Sistem Digital berupa lembar wawancara untuk mendapatkan informasi berupa kebutuhan apa saja dalam pengembangan modul elektronik. Observasi merupakan teknik pengumpulan data dengan cara mengamati secara langsung ke lapangan untuk memperoleh keterangan mengenai proses pembelajaran matakuliah Sistem Digital.. Teknik komunikasi tidak langsung adalah cara mengumpulkan data dengan menggunakan alat yaitu angket/kuisoner. Kuesioner atau angket dalam penelitian ini ditujukan kepada ahli media, ahli materi untuk menilai tingkat kelayakan. Angket untuk mahasiswa digunakan untuk mengetahui respon mahasiswa terhadap modul elektronik Sistem Digital.

Untuk teknik analisis data menggunakan data display yaitu menyajikan produk dari pengembangan modul yang telah dikembangkan kemudian dipaparkan hasil validasi yang diperoleh dari tim validator mengenai produk yang dihasilkan. Kemudian menggunakan statistik deskriptif untuk menganalisis data dengan cara mendeskripsikan atau menggambarkan data yang telah terkumpul. Revisi produk didasarkan atas masukan dari uji kelayakan. Langkah ini akan semakin menyempurnakan produk yang sedang dikembangkan. Produksi masal merupakan tahap akhir dan siap digunakan oleh masyarakat. Peneliti membatasi langkah-langkah model pengembangan hanya sampai uji coba pemakaian saja untuk mengetahui respon mahasiswa mengenai aplikasi Sistem Digital.

\section{HASIL DAN PEMBAHASAN}

Potensi dan masalah yaitu belum adanya modul elektronik sehinga kemandirian peserta didik masih kurang, dan media maupun bahan ajar yang digunakan dosen dalam mengajar masih menggunakan lembar kerja mahasiswa, sehingga proses pembelajaran di laboratorium komputer tersebut masih kurang optimal. Tahap selanjutnya yaitu pengumpulan data yaitu peneliti menentukan cakupan materi yang akan disajikan dalam modul elektronik yaitu materi pengenalan sistem digital, sistem bilangan, konversi sistem bilangan, aljabar boole, dan gerbang logika, encoder decoder dan multiplexer demultiplexer. Kemudian peneliti membuat desain 
modul elektronik aplikasi Sistem Digital. Untuk mengembangkan produk berupa modul elektronik Sistem Digital, peneliti membuat terlebih dahulu desain modul elektronik sampai pada pembuatan produk. Tahap awal dalam pembuatan produk modul elektronik adalah dengan menggunakan Macromedia Flash 8.

Tampilan halaman cover modul elektronik berisi judul modul elektronik, dan tombol navigasi utk masuk ke menu utama.Tampilan halaman cover modul elektronik dapat dilihat pada Gambar 2.

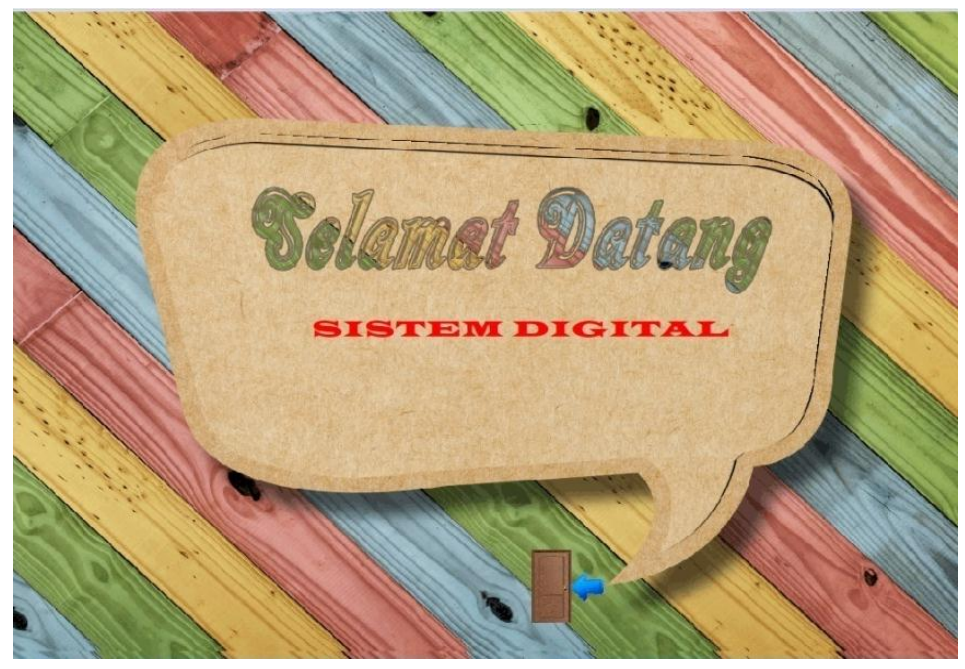

Gambar 2. Desain Halaman Cover Modul Elektronik

Tampilan halaman judul modul elektronik berisi judul modul elektronik dan tombol navigasi (Standar Kompetensi dan Kompetensi Dasar, Indikator, tujuan, Materi, Evaluasi dan Penulis). Tampilan halaman utama modul elektronik pada Gambar 3.

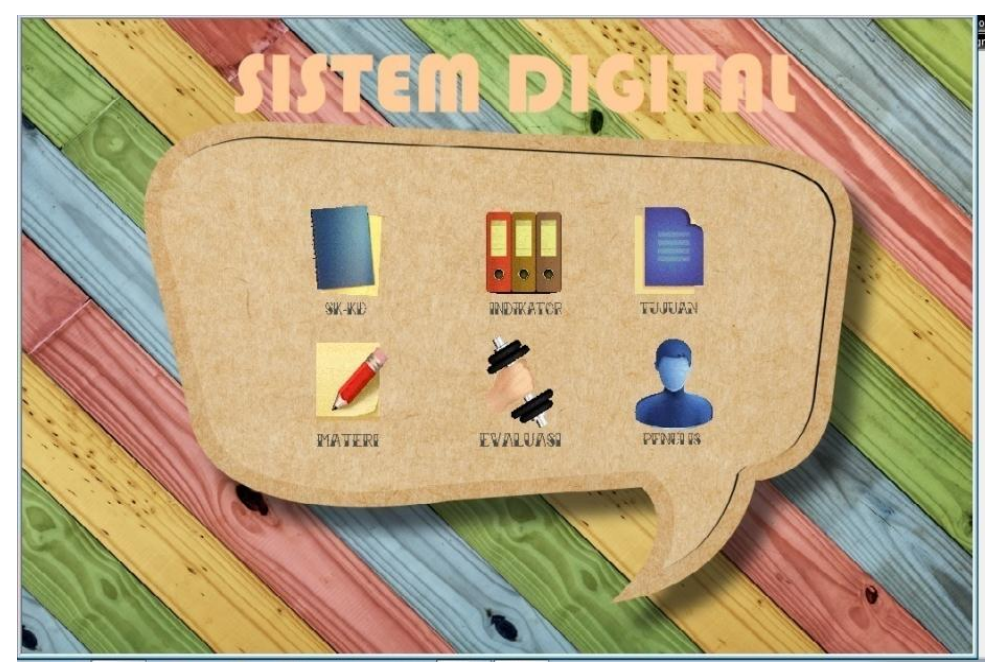

Gambar 3. Tampilan Halaman Menu Utama 
Tampilan SK-KD berisi uraian tentang standar kompetensi dan kompetensi dasar. Tampilan SK-KD dapat lihat pada Gambar 4.

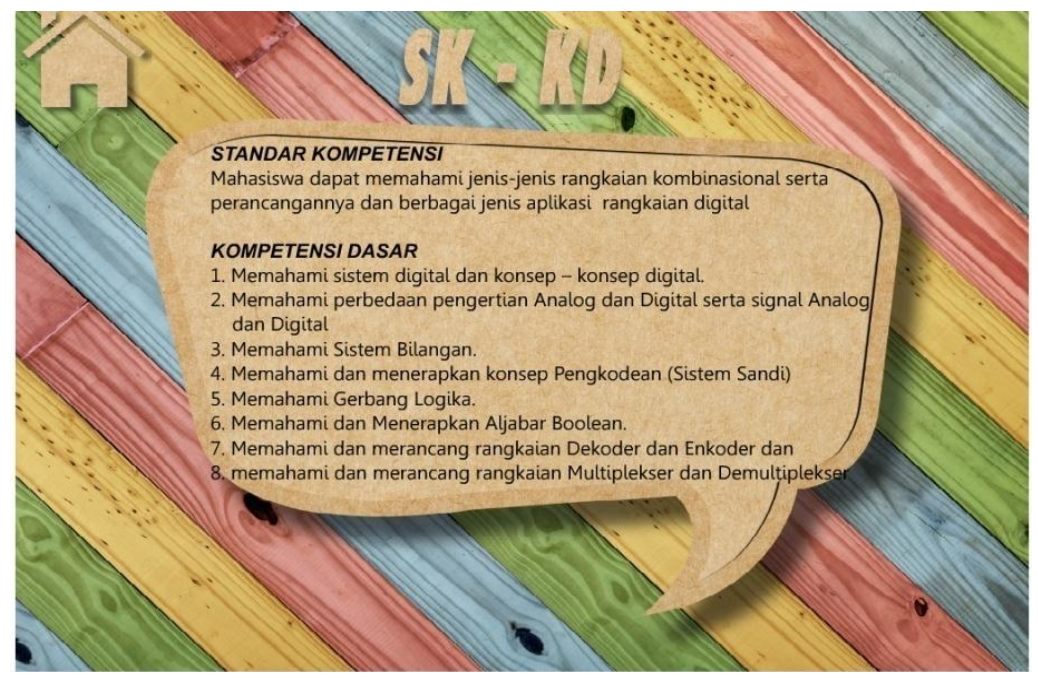

Gambar 4. Tampilan SK-KD Modul Elektronik

Tampilan indikator berisi tentang pencapaian mahasiswa pada mata kuliah Sistem Digital. Tampilan indikator disajikan pada Gambar 5.

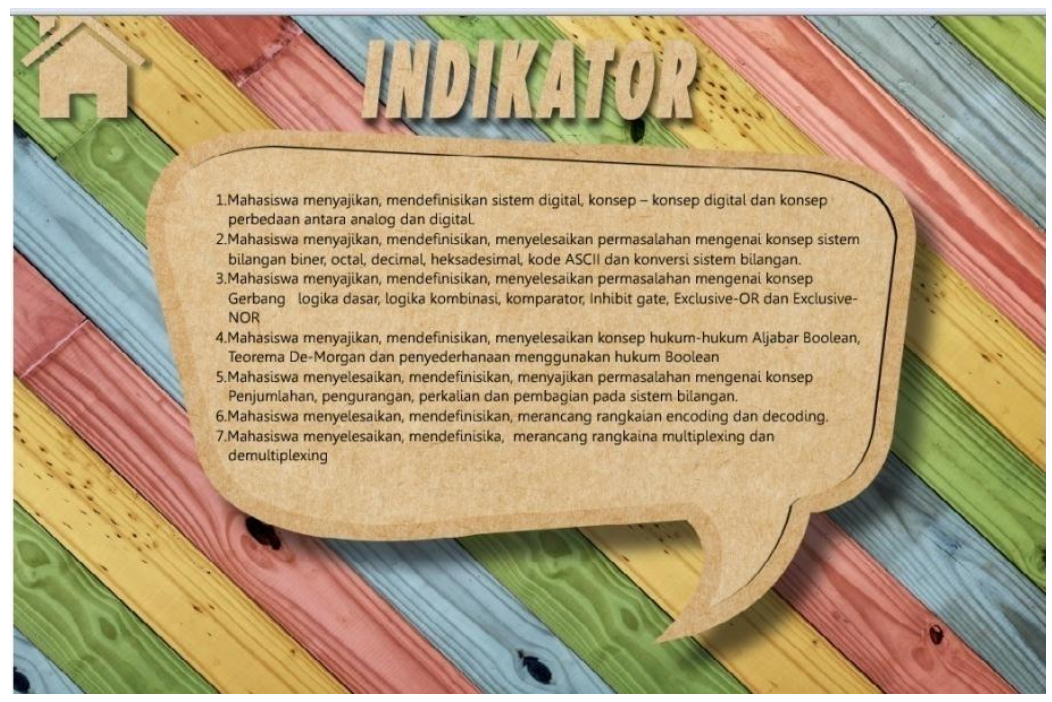

Gambar 5. Tampilan Tujuan Modul Elektronik

Tujuan berisi tentang tujuan setelah mempelajari modul elektronik. Tampilan tujuan pembelajaran dapat dilihat pada Gambar 6. 


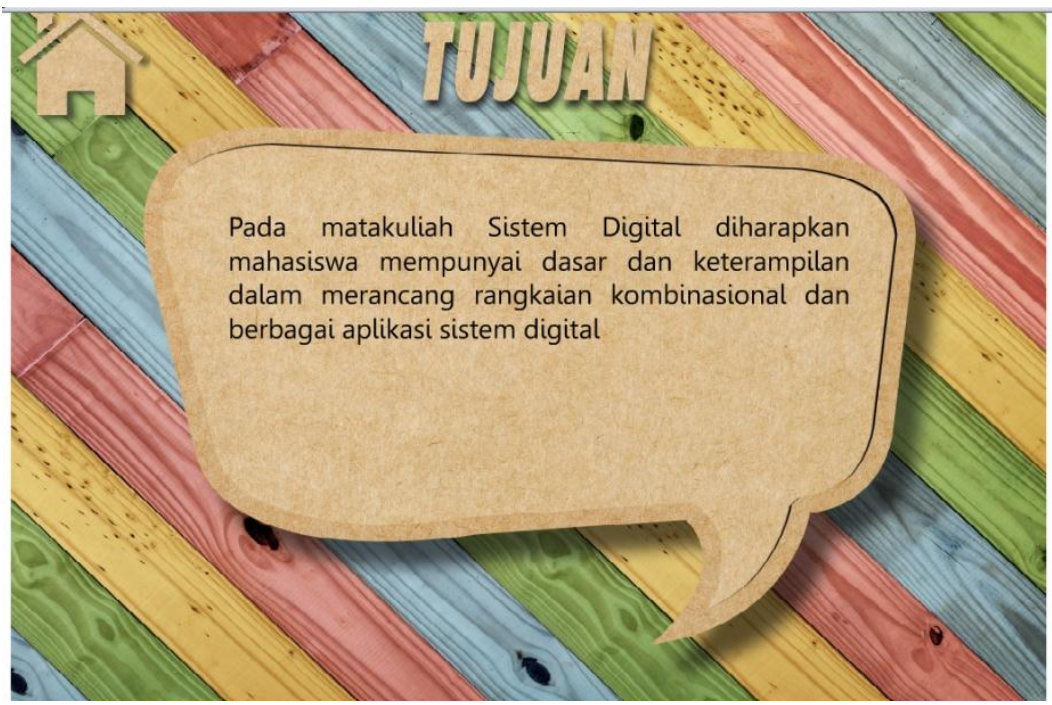

Gambar 6 Tampilan Tujuan Modul Elektronik

Dalam setiap judul pada kegiatan belajar terdapat uraian materi secara runtut yang diharapkan dapat memudahkan mahasiswa dalam belajar mandiri saat menggunakan modul elektronik. Contoh tampilan materi pada modul elektronik dapat dilihat pada Gambar 7.

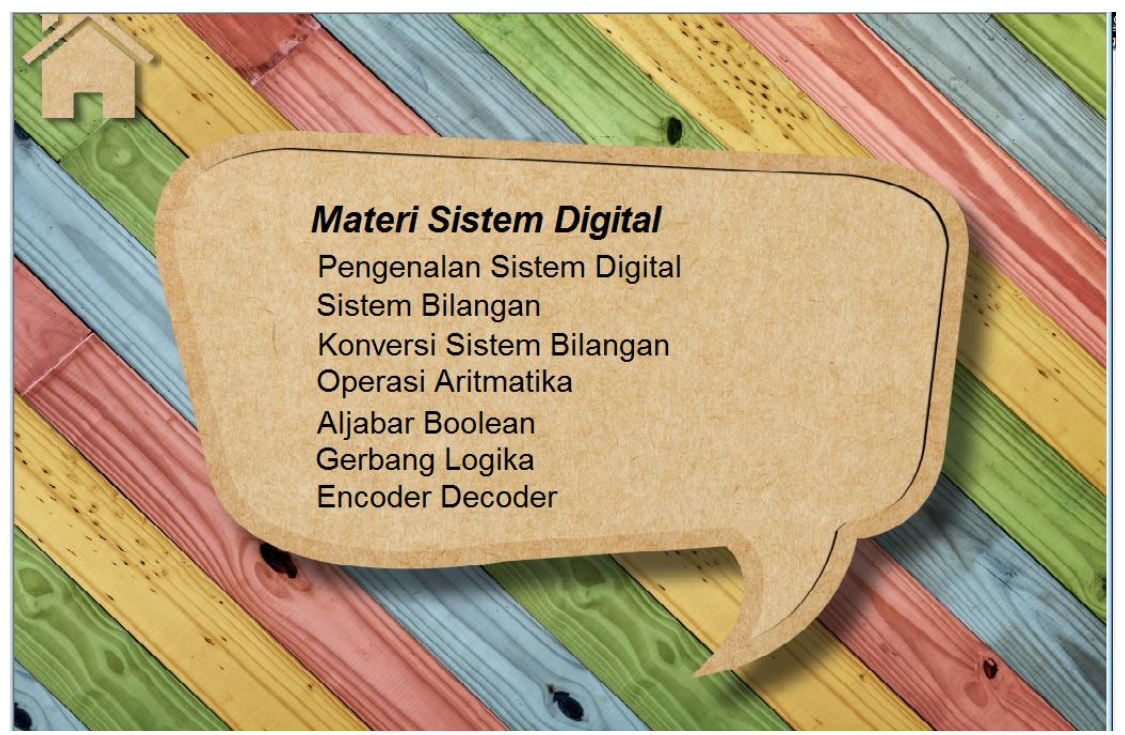

Gambar 7. Tampilan Materi Modul Elektronik

Tampilan uraian modul elektronik berisi uraian materi Sistem Digital. Tampilan uraian materi dapat dilihat pada Gambar 8. 


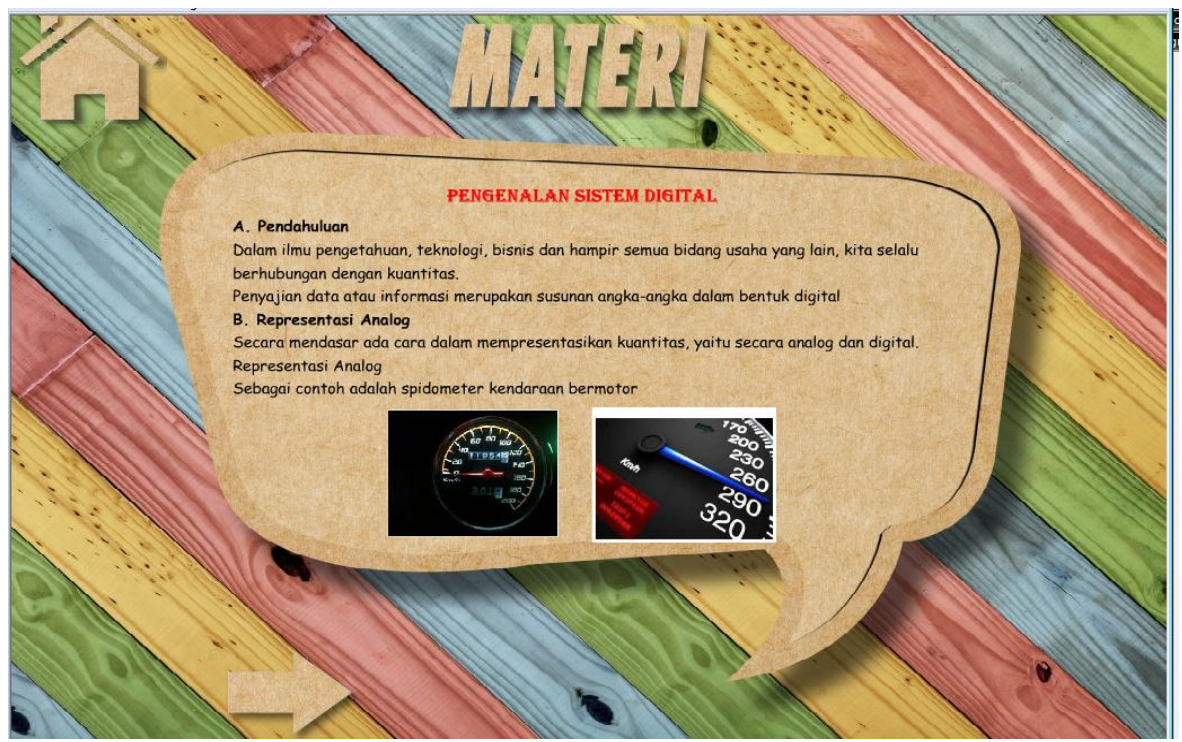

Gambar 8. Tampilan Materi Modul Elektronik

Evaluasi digunakan untuk mengukur kemampuan mahasiswa dalam mempelajari keseluruhan materi yang disajikan dalam modul elektronik. Tampilan halaman evaluasi disajikan pada Gambar 9.

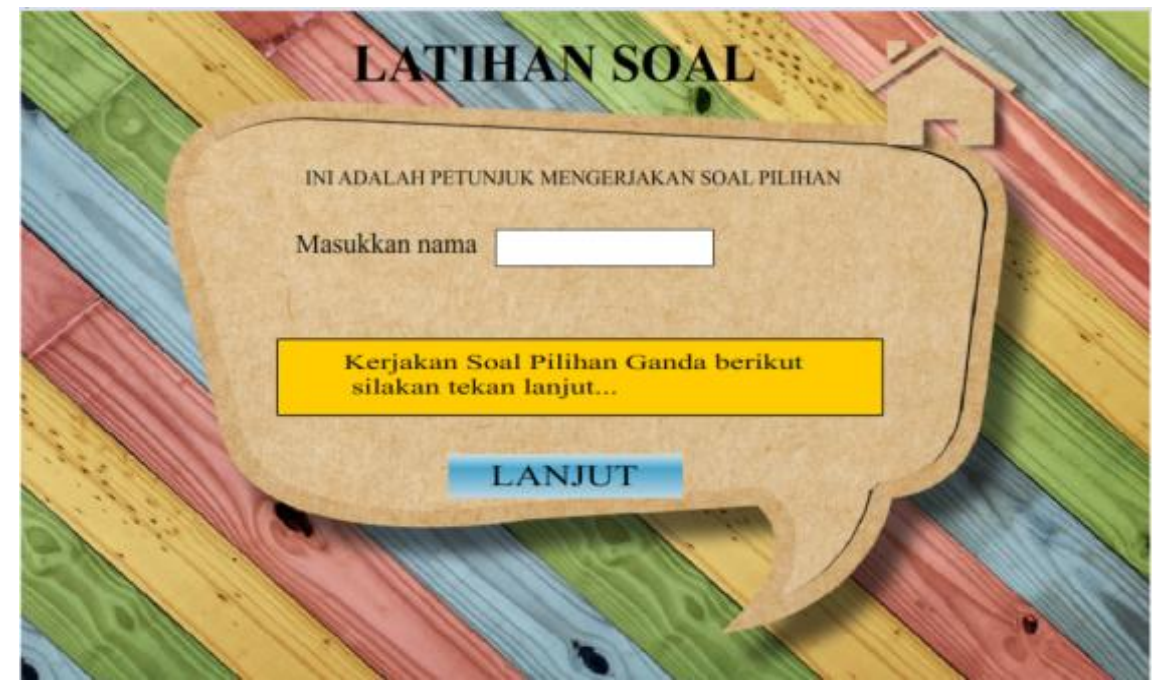

Gambar 9. Tampilan halaman evaluasi Modul Elektronik

Pada tampilan evaluasi modul elektronik, mahasiswa memasukkan nama kemudian menekan tombol lanjut. Tampilan isi soal berupa pilihan ganda dapat dilihat pada Gambar 10. 


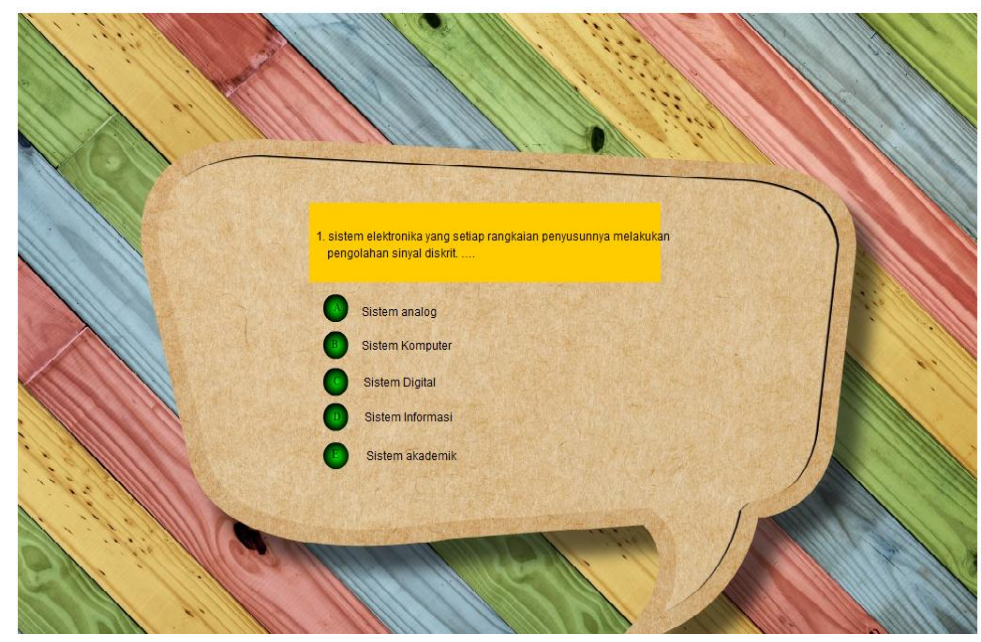

Gambar 10. Tampilan soal Modul Elektronik

Setelah mahasiswa mengerjakan soal pilihan ganda yaitu 20 butir soal, hasil evaluasi dapat dilihat pada gambar 11 .

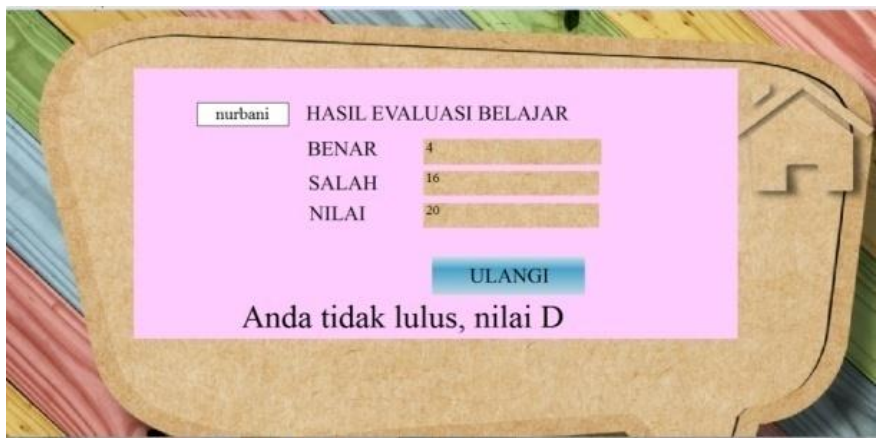

Gambar 11. Tampilan Hasil Evaluasi Modul Elektronik

Setelah modul elektronik dikemas dalam bentuk Compact Disc (CD) serta instrumen penelitian telah divalidasi, maka langkah selanjutnya adalah melakukan validasi modul elektronik kepada dosen ahli materi dan dosen ahli media untuk mengetahui kelayakan produk pengembangan tersebut. Dosen ahli materi terdiri dari dua orang dosen IKIP-PGRI Pontianak yang pernah mengajar materi Sistem Digital. Selain dosen ahli materi, modul elektronik juga dinilai oleh dosen ahli media yaitu dua orang dosen IKIP-PGRI Pontianak yang ahli dalam bidang media pembelajaran.

Setelah masukan-masukan dari dosen ahli materi dan dosen ahli media maka produk awal modul elektronik siap untuk diujicobakan kepada mahasiswa. Uji coba dilakukan pada mahasiswa semester 3 dengan jumlah sampel 82 orang. Peneliti memandu secara langsung ujicoba dengan didampingi dosen pengampu matakuliah Sistem Digital. Uji coba berjalan 
dengan lancar, para mahasiswa sangat antusias menggunakan modul elektronik dan aktif melakukan apa yang diperintahkan dalam modul elektronik tersebut. Proses uji coba diakhiri dengan memberikan angket kepada mahasiswa untuk mengetahui respon mahasiswa terhadap modul elektronik yang telah dibuat. Setelah ujicoba selesai dan dirasa tidak ada masukan untuk perbaikan modul elektronik maka produk final modul ektronik bisa digunakan dalam proses pembelajaran.

Kelayakan produk pengembangan modul elektronik dinilai oleh dua orang dosen ahli materi yaitu dosen IKIP-PGRI Pontianak yang ahli dalam bidang aplikasi Sistem Digital. Hasil perhitungan angket kelayakan oleh dosen ahli materi dapat dilihat pada Tabel 1.

Tabel 1. Rekapitulasi Kelayakan Ahli Materi

\begin{tabular}{ccc}
\hline Validator & Jumlah Skor & Kriteria \\
\hline Ahli Materi 1 & 110 & Layak \\
Ahli Materi 2 & 95 & Layak \\
Rata-rata & 102,5 & Layak \\
\hline
\end{tabular}

Berdasarkan Tabel 1 dapat dilihat bahwa rata-rata penilaian dosen ahli materi adalah 102,5. Hasil tersebut menunjukkan bahwa modul elektronik yang dikembangkan dilihat dari 27 item termasuk dalam kriteria layak.

Kelayakan media modul elektronik dinilai oleh dua orang dosen ahli media yaitu dosen IKIP-PGRI Pontianak yang ahli dalam bidang media pembelajaran. Hasil perhitungan angket kelayakan media pembelajaran dapat dilihat pada Tabel 2.

Tabel 2. Rekapitulasi Kelayakan Ahli Media

\begin{tabular}{lcc}
\hline \multicolumn{1}{c}{ Validator } & Jumlah Skor & Kriteria \\
\hline Ahli Media 1 & 97 & Layak \\
Ahli Media 2 & 92 & Layak \\
Jumlah Rata-rata Penilaian & 94,5 & Layak \\
\hline
\end{tabular}

Berdasarkan Tabel 2 hasil perhitungan dapat dilihat bahwa rata- rata penilaian dosen ahli media adalah 94,5. Hasil tersebut menunjukkan bahwa modul elektronik yang dikembangkan termasuk dalam kriteria layak.

Respon mahasiswa terhadap produk modul elektronik yang dikembangkan diketahui berdasarkan hasil angket yang diberikan dan diisi oleh mahasiswa pada saat ujicoba. Respon mahasiswa pada ujicoba dilakukan pada mahasiswa semester 3 Program Studi P.TIK dengan 
sampel 53 orang mahasiswa. Hasil perhitungan angket respon mahasiswa terhadap modul elektronik pada ujicoba dapat dilihat pada Tabel 3.

Tabel 3. Rekapitulasi Angket Respon Mahasiswa

\begin{tabular}{cccc}
\hline $\begin{array}{c}\text { Rata-rata } \\
\text { Responden }\end{array}$ & $\begin{array}{c}\text { Skor } \\
\text { Mahasiswa }\end{array}$ & $\begin{array}{c}\text { Skor } \\
\text { Angket }\end{array}$ & Kriteria \\
\cline { 2 - 4 } & 106 & 3,9 & Baik \\
\hline
\end{tabular}

Berdasarkan Tabel 3 dapat disimpulkan bahwa respon mahasiswa terhadap produk pengembangan modul elektronik ditunjukkan dengan skor rata-rata mahasiswa pada ujicoba adalah 108 dengan skor angket adalah 4. Hasil rata-rata skor angket respon siswa tersebut menunjukkan bahwa modul elektronik yang dikembangkan termasuk dalam kriteria baik. Dengan demikian modul elektronik Sistem Digital mudah digunakan oleh mahasiswa.

\section{SIMPULAN}

Adapun kesimpulan dari penelitian ini adalah sebagai berikut pengembangan modul elektronik menggunakan model Borg and Gall yang memiliki beberapa tahap yaitu mencari potensi dan masalah, pengumpulan data, desain produk, validasi desain, revisi desain, validasi produk, uji coba pemakaian produk dan revisi produk. Hasil penilaian modul elektronik oleh dosen ahli materi diperoleh skor 102,5 dengan kriteria layak dan hasil penilaian modul elektronik oleh dosen ahli media diperoleh skor 94,5 dengan kriteria layak. Sehingga penilaian modul elektronik berdasarkan ahli materi dan ahli media termasuk dalam kategori layak. Sedangkan respon mahasiswa terhadap modul elektronik dalam ujicoba sampel 82 orang mahasiswa diperoleh rata-rata skor angket 3.9 dengan kriteria baik. Berdasarkan data tersebut dapat disimpulkan bahwa modul elektronik Sistem Digital yang dikembangkan layak dan baik digunakan dalam proses pembelajaran.

\section{DAFTAR PUSTAKA}

Mudhofir. (1990). Prinsip-prinsip pengelolaan pusat sumber belajar. Bandung: Wahana Press.

Najikhah, F., Budiyono, B., \& Wardi, W. (2016). Kefektifan MPI game edukasi terhadap hasil belajar ipa di kelas 1 sekolah dasar. Indonesian Journal of Curriculum and Educational Technology Studies, 4(2), 58-65. 
Ningsih, D. R. S., Hasyim, A., \& Fitriawan, H. (2013). Pengembangan bahan ajar multimedia interaktif srandar kompetensi menggambar dengan perangkat lunak autocad bagi siswa smk di lampung. Jurnal Teknologi Informasi Komunikasi Pendidikan, 2(1), 1-15.

Sugiyono. (2014). Metode penelitian pendidikan (pendekatan kuantitatif, kualitatif \& rnd). Bandung: Alfabeta. 